\title{
LEADERSHIP STYLES AND THEIR IMPACT ON LEAN SIX SIGMA PRACTICES IN INDIAN INDUSTRIES
}

\author{
K. Srimathi ${ }^{1 *} \&$ K. Narashiman ${ }^{1}$
}

\section{ARTICLE INFO}

\begin{tabular}{|c|c|}
\hline $\begin{array}{l}\text { Article details } \\
\text { Submitted by authors } \\
\text { Accepted for publication } \\
\text { Available online }\end{array}$ & $\begin{array}{l}17 \text { Feb } 2020 \\
14 \text { Dec } 2020 \\
28 \text { May } 2021\end{array}$ \\
\hline \multicolumn{2}{|c|}{$\begin{array}{l}\text { Contact details } \\
\text { * Corresponding author } \\
\text { srimathi.k@annauniv.edu.in }\end{array}$} \\
\hline \multicolumn{2}{|c|}{$\begin{array}{l}\text { Author affiliations } \\
1 \text { AU-TVS Centre for Quality } \\
\text { Management, Anna University, } \\
\text { Guindy, Chennai, TamilNadu } \\
600025 \text {, India }\end{array}$} \\
\hline $\begin{array}{l}\text { ORCID® identifiers } \\
\text { K.Srimathi } \\
\text { https://orcid.org/0000-0 }\end{array}$ & $002-7796-2801$ \\
\hline $\begin{array}{l}\text { K.Narashiman } \\
\text { https://orcid.org/0000-0 }\end{array}$ & $002-4868-2042$ \\
\hline
\end{tabular}

DOI

http://dx.doi.org/10.7166/32-1-2323

\section{ABSTRACT}

The study aims to investigate the impact of different leadership styles on the Lean Six Sigma practices of manufacturing and service industries in India. In this study, the relationships between different leadership styles and Lean Six Sigma practices were determined by using Welch's test and regression analysis. Welch's test proved that there is a significant difference between the manufacturing and service sectors in the case of the instrumental and supportive leadership styles, but no significant difference in the participative leadership style while practising Lean Six Sigma. The results of Welch's test showed that the service sectors were more interested in Lean Six Sigma-based practices. The results also revealed that the relationships between the participative, supportive, and instrumental leadership styles and Lean Six Sigma practices were highly significant for both the manufacturing and the service sectors in India. This finding offers a managerial perspective that these three types of leadership styles could potentially ensure the eventual improvement of Lean Six Sigma practices.

\section{OPSOMMING}

Hierdie studie ondersoek die impak van verskillende leierskapstyle op die Lenige Ses-Sigma praktyke van vervaardiging- en diensverskaffingsnywerhede in Indië. Die verhoudings tussen verskillende leierskapstyle en Lenige Ses-Sigma praktyke is bepaal deur Welch se toets en regressie analise. Welch se toets het bewys dat daar 'n noemenswaardige verskil tussen die twee sektore is in die geval van instrumentele en ondersteunende leierskap. Daar is egter geen noemenswaardige verskil vir die deelnemende leierskapstyl wanneer Lenige Ses-Sigma beoefen word nie. Die resultate van Welch se toets toon dat diensverskaffingsnywerhede meer in Lenige Ses-Sigma praktyke belangstel. Die resultate toon ook dat die verhoudings tussen die verskillende leierskapstyle noemenswaardig is vir beide van hierdie sektore in Indië. Hierdie bevindinge kan moontlik verseker dat Lenige Ses-Sigma praktyke in Indië verbeter word.

\section{INTRODUCTION}

In an increasingly globalised world, it is usually discovered that the difficulties faced by leaders who deploy Lean Six Sigma (LSS) practices have all the hallmarks of being progressively powerful, and cannot be met by using past solutions. Thus the future of LSS practices requires new leaders who are capable of successfully adopting various leadership styles for the enhanced execution of LSS practices. The objective of outstanding leadership and the adoption of LSS practices is to combine to improve internal processes, resulting in good organisational performance. Nonetheless, there is still a gap in the available research literature on leadership styles when implementing LSS. Lean and Six Sigma have become the most frequently used business systems for implementing continuous improvement in the manufacturing and service sectors [1]. Continuous improvement is the primary objective of any organisation, assisting it to achieve quality and operational excellence and to improve performance. Thomas, Barton and Okafor [2], Assarlind, Gremyr and Backman [3], and Snee [4] describe LSS as a highly organised methodology for enhancing performance, creating leading organisations and consumer loyalty, and achieving bottom-line results. The link between various leadership styles and LSS practices seems, by all accounts, to be relatively unknown among the manufacturing and service sectors in India. Although numerous investigations have 
been done into the relationship between leadership styles and total quality management, the particular attributes of Lean and Six Sigma practices ([5],[6],[7],[8],[9]), which are expected to lead to continuous improvement, have not yet been categorised. Thus this study aims to discover which leadership styles might be more helpful in implementing LSS in Indian manufacturing and service industries.

\subsection{Objectives}

The main objective of this paper is to understand better the impact of different leadership styles - in particular, the participative, supportive, and instrumental leadership styles - on LSS practices in Indian manufacturing and service industries, and to explore whether there is any difference in the leadership styles while practising LSS in those industries.

\subsection{Literature review}

The literature review has been divided into three sections. The first discusses LSS practices; the second discusses the leadership styles in detail; and the third focuses on the relationship between LSS and the leadership styles.

\subsubsection{Lean Six Sigma}

The subject of how to address the challenge of quality standards and avoiding non-value-adding activities has concerned analysts and professionals for two decades. In the last decade, quality enhancement was described by two noteworthy methodologies: Lean improvement, which plans to handle process effectiveness by eliminating non-value-adding steps and activities in a process [10]; and Six Sigma, which confines the process's variation of priorities by revealing the entire process towards the mean. Schroeder et al. [11] proposed that Six Sigma, when implemented in an organisation, brought about a more enhanced organisational performance than other quality methodologies. The development of the two practices in combination is named 'Lean Six Sigma' (LSS). While understanding the need to offer business value to the customer in a rapidly changing business environment and to consider the customer's requests, the combination of Lean development and Six Sigma is by all accounts a promising endeavour, and has received increasing attention in recent years.

Various authors ([12],[13],[14]) proposed consolidating the benefits of both approaches to create a quality enhancement tool. Dahlgaard and Dahlgaard-Park [15] analysed many quality-enhancement initiatives, advocating that the roadmaps of Lean and Six Sigma be considered as new choices for total quality management roadmaps. The cutting-edge perspective of value improvement that is pervasive in earlier essential phase-based methodologies has been replaced by various statistical tools and innovative techniques. This has increased organisational productivity and business value for customers through process improvements.

For the unified LSS, there is appears to be little unanimity about its definition. Proposing a early definition of LSS, based on a grounded theory approach, Laureani and Antony [7] concluded that LSS is a business enhancement methodology that involves maximising shareholder value by enhancing quality, speed, consumer loyalty, and costs; it accomplishes this by merging tools and principles from both Lean and Six Sigma. They affirmed that researchers need to detail a less ambiguous and more fruitful understanding of LSS with the goal of upgrading it to offer better implementation strategies.

In recent years, research articles have focused on the benefits of the application of LSS practices in the industry. Published surveys that analysed the relationship between leadership styles and LSS found discussion of the topic to be scarce. The literature related to similar concepts and relationships needs to be considered to gain a deeper understanding of this area. Many authors argue that Six Sigma is an extension of the broader concept of total quality management (TQM) [16], so that studies related to Lean, Six Sigma, and TQM can be taken to evaluate the relationship between leadership styles and LSS. Based on the work of $\mathrm{Zu}$ et al. [17], the present author has proceeded with this empirical study to discover the relationship between leadership styles and LSS practices. The LSS practices as streamlined by Zu et al. [17] are top management support (TMS), customer relationship (CR), supplier relationship (SR), workforce management (WM), quality information (QI), role structure (RP), structured procedure (SP), focus on metrics (FM), process management (PM), and product/service design (PSD), which are the most important factors of total quality management and LSS. The author has adopted the same practices for this study in the Indian context.

Top management support has been highlighted by most researchers and authors as contributing to quality performance. The quality of the physical product is not enough to sustain benefits. Customer relationships 
are a basic piece of the framework for improving quality performance. Top management support and commitment, which most papers have mentioned, is simply another name for leadership.

\subsubsection{Leadership styles}

Previous leadership theories and practices have concentrated on what leaders do, how they do it, and what leadership is for. The idea of leadership has been misinterpreted by several groups. Some people have thought that leadership is about being first or most dominant. McNamara [18] defined a leader as someone who establishes people's attitudes to work and who influences individuals to adopt them.

Chemers [19] gave a different definition of leadership: leadership implies the process of social impact in which one individual can offer guidance and support to others in order to achieve a common task. Lok and Crawford [20] advocated that culture and leadership styles have real impacts on people. This is because leaders are the ones who set the tone of the organisation, characterise its qualities and standards, and create and keep up a persona of what the organisation resembles [21]. The above definitions have similarities at some points. It needs to be said that leadership behaviour is one of the components that promotes the achievement of a business's goals. To lead in a challenging environment, a leader must continue learning, and should have confidence in the tasks that are executed and in their subordinates. The responsibilities of a leader are not simple, since the role requires a high level of responsibility in accomplishing the task. In this study, three types of leadership style are in focus: the participative, supportive, and instrumental leadership styles, as proposed by Ogbonna and Harris [22].

\subsubsection{Participative leadership style}

The participative leadership style, which is characterised by joint decision-making, or at least a sharing of decision-making by a superior and their colleagues [23], offers an assortment of potential advantages. Horsfall [24] argued that the participative leader concentrates more on building consensus in an organisation in order for it to meet its objectives.

\subsubsection{Supportive leadership style}

The factors that are nearest to those of a supervisor's help in building self-assurance have been systematised in the organisational literature in Bowers and Seashore's [25] theory of leadership. The management function of support is defined as the manager's behaviours that improve subordinates' feelings of personal worth. This idea is adapted from Halpin and Winer's [26] notion of 'consideration' and Likert's [27] principle of supportive leadership [28]. House [29] characterised a supportive leader as someone who gives instructive, instrumental, and appraisal support to subordinates. The path-goal theory formulated by House [29] states that the leader's job is to assist followers to achieve their objectives by specifying a direction, providing support, and ensuring that their goals are well-matched with the organisation's goals.

\subsubsection{Instrumental leadership style}

The instrumental leadership style is similar to directive leadership, and is intended to measure the degree to which leaders indicate desires, allocate assignments, and set up procedures [30]. As an result, based on a significant and detailed critique of existing leadership theories, Antonakis [31] and House [32] commented that instrumental leadership addresses an important gap in the field of leadership: it incorporates leadership behaviours that are not part of the transformational, transactional, or laissez-faire leadership styles. According to Rowold [33], there are four dimensions to the instrumental leadership style environmental monitoring, strategy formulation, path-goal facilitation, and outcome monitoring - and he concluded that the instrumental leadership style is a combination of the transformational and transactional leadership styles.

\subsubsection{LSS practices and leadership styles}

A prominent part of effective quality management is leadership [34]. The Malcolm Baldrige National Quality Award's criteria for performance excellence are the most broadly used quality criteria for quality management [35]. One of its main criteria is leadership [36] that helps to accomplish quality performance. This category emphasises how senior supervisors can manage an organisation and inspire excellent performance. It also encourages visionary leadership as a main value and idea. Quality 'experts' stress that leadership is essential for the effective implementation of total quality management [37]. To study the effects of leadership style and quality management practices on company performances, Idris and Ali [36] performed a study using empirical evidence from business firms in Malaysia. They found that the capacity to adjust to change is basic to survival in the new global economic order. This ability, which is like transformational leadership, combined with the ability to adopt best practice, can lead to organisational success. The study found that transformational leadership - when combined with best practice management - can enhance financial performance. It can thus be concluded that a compelling approach to administration can achieve the needed organisational change. Leaders create the vision and, through successful communication, they motivate their followers to achieve that vision. 
The concepts of initiative styles and quality management practices are critical in organisations. The use of these ideas frequently decides how organisations accomplish their objectives and goals [38]. The blend of abilities, attributes, characteristics, and strategies for each style will yield a powerful leadership model that is fit for driving quality management. An integration of these leadership styles will drive forward the leader's capacity to influence the organisation successfully, and so affect quality management practices. To begin with, it is imperative to understand the role of leadership styles in LSS practices in manufacturing and service industries in India, particularly when the outcomes of studies on specific leadership styles have not been clear or consistent.

The significance of leadership has regularly been stressed by authors in the field of continuous improvement ([39],[40],[41]), and research has demonstrated that effective leaders have particular characteristics that are essential to being successful [42]. Although many organisations have attempted to turn LSS into a triumph, because of various factors leading to failure [43] - and given that leadership has been recognised as a critical success factor ([44],[45],[5]) - this study turns its attention to research specifically which leadership traits and characteristics are helpful in the effective execution of LSS in organisations.

Timans et al. [46] identified internal opposition, inaccessible assets, changing business centres, and the absence of leadership as the most important aspects that hinder LSS implementation. Laureani [47] investigated the relationship among leadership and LSS deployment in organisations; because leadership has been defined as a basic and critical success factor in LSS deployment in organisations, he identified the characteristics of leadership that are increasingly helpful in successful implementation through qualitative analysis.

The role of leadership in quality management has not been given a lot of attention in the leadership literature [48]. The present author emphasises that his hypothetical framework opens the way to enquiring into leadership behaviours by investigating the conduct of both the explicit and the general behavioural dimensions related to a total quality management philosophy, which has not been addressed in the traditional behavioural paradigm of leadership research.

A comparable proposal is offered by Berson and Linton [49], who note the need for future research in analysing the connection between leadership styles and quality management practices. Ovretveit [50] argues that some of the current research has raised issues about measuring the impact that managers and the management's activities have on quality improvement. Sousa and Voss [51] also recommended that further research be undertaken to inspect the relationship between quality management and leadership styles. Thus, based on the identified gaps, the researcher is interested in investigating the effect of leadership styles - specifically, the participative, supportive, and instrumental aspects - on LSS practices in Indian manufacturing and service industries.

Jacobs [8] asserted that leadership styles have a profound effect on LSS implementation. Jacobs studied the effects of four types of leadership style -transformational, participative, instrumental, and supportive - on LSS practices such as role structure, structured procedures, focus on metrics, process management, and process/service design. da Costa Nogueira et al. [9] also suggested that, rather than following a single style of leadership, it is better to have a mixed leadership style that leads to a successful implementation of Lean management; and so she discussed the relationship between four types of leadership style transformational, transactional, directive, and empowering - and the implementation of Lean practices. Assen [52] studied the impact of three types of leadership style -transformational, servant, and empowering - on lean practices, and concluded that there was no relationship between contemporary leadership styles and lean practices. Kumar [53] discussed the relationship between leadership styles such as transformational, adaptive, servant, rational, and kinesthetic with TQM constructs such as innovation and continuous improvement. The results showed a positive and significant relationship between the two constructs. Alefari et al. [54] examined the impact of various leadership styles during Lean implementation. The leadership styles selected for that study were based on situational leadership theory, which focuses on telling, coaching, supporting, and delegating . A survey of UAE manufacturing companies resulted in the coaching and supporting styles being adopted by managers to enhance the performance of employees. Burawat [55] examined the structural relationships among transformational leadership, sustainable leadership, lean manufacturing practices, and sustainability performance in Thai SME manufacturing industries. The results showed that transformational leadership had an impact on Lean manufacturing, whereas sustainable leadership did not.

To summarise, only a few recent studies have explored the relationship between LSS and leadership styles, and more studies are required to reveal the link between LSS and leadership styles in their behavioural 
aspects. This research mainly investigated leadership styles from a behavioural perspective, and how they are linked in the context of LSS practices. A leadership style can be portrayed as the strategy for providing direction, using plans, and motivating individuals [56]. This paper investigates the relationship between the three types of leadership style proposed by Ogbonna and Harris [22] - participative, supportive, and instrumental - and the ten LSS practices proposed by Zu et al. [17]. Recent research papers have mostly explored the relationship of quality management practices with the transformational, transactional, empowering, servant, and directive leadership styles, but not with the participative, supportive, and instrumental styles. Thus this study sought to explore the relationship between the most often identified quality management practices with these three types of leadership style.

\section{MATERIAL AND METHODS}

\subsection{Research methodology}

The purpose of the present study was to determine the impact of leadership styles on LSS practices in manufacturing and service industries in Tamil Nadu, India. Based on simple random sampling, the following industries were selected for the survey. The industries related to manufacturing used in this study were mainly in the automobile and auto components, engineering, garments, textile products, chemicals, and plastics industries. The service sector respondents used in this study were mainly from information technology, e-publishing, business process outsourcing, and financial services.

A quantitative analysis style was adopted to gather information and check the hypotheses. The source of the industry database was the Centre of Quality Management, which is under the governance of the university. The target population for this study was managers and team leaders. The survey respondents were the LSS professionals working with LSS projects. A Google Form was created, and the link was forwarded randomly to 400 respondents; there was an equal distribution of questionnaires between the manufacturing and service sectors. The response rate was 78 per cent (313 responses), which is a good response [57]; and the analyses were conducted using SPSS 26.0. The questionnaire used for the survey had three sections. The first section had questions related to the demographic details of the respondents; the second section had questions related to LSS practices; and the third section had questions related to leadership styles.

In this study, the independent variable was leadership styles and the dependent variable was LSS practices. The LSS practices dimensions were adopted from the research work of Zu et al. [17], which highlighted ten dimensions; and the questions related to leadership style dimensions were adopted from Ogbonna and Harris [22], who promoted the innovative, competitive, and community culture dimensions - the cultural dimensions most required for quality improvement. Finally, after exploratory factor analysis, the ten dimensions of the LSS practices were reduced to eight. The three dimensions of the leadership styles were included in the study after the exploratory factor analysis, which led to the removal of certain measurement items based on the loadings.

The leadership style dimensions are the participative leadership style (PLS), the supportive leadership style (SLS), and the instrumental leadership style (ILS), as shown in Figure 1. The LSS dimensions after exploratory factor analysis were workforce management (WM), quality and information (QI), customer relationship (CR), role structure (RS), structured procedure (SP), focus on metrics (FM), process management PM), and product/service design (PSD), as shown in Figure 2. All of these items were rated on a five-point scale, ranging from 1 (strongly disagree) to 5 (strongly agree). The LSS practices and leadership styles together had 50 measurement items; the questionnaire consisted of 61 items in total, of which 11 items sought the demographic details of the respondents. Reliability and validity analyses were conducted, and are reported in Section 3.2.

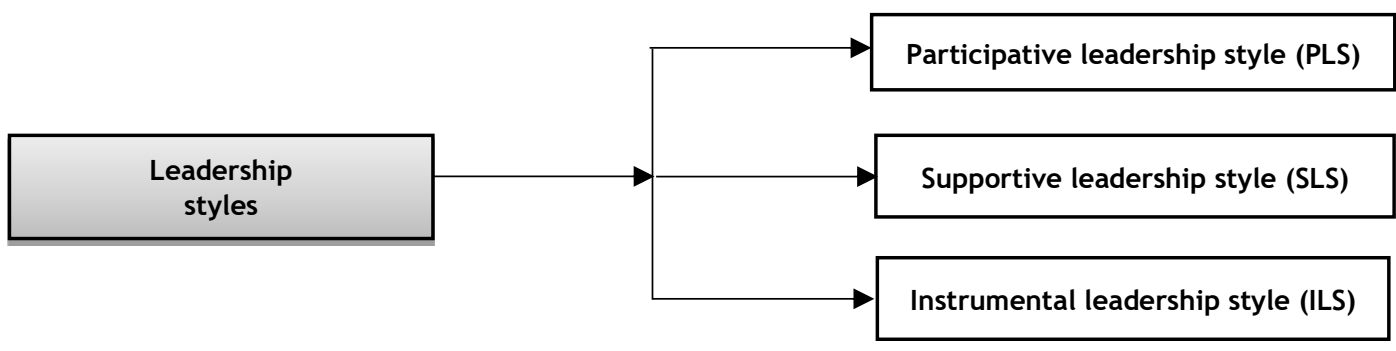

Figure 1: Leadership styles (independent variable) 


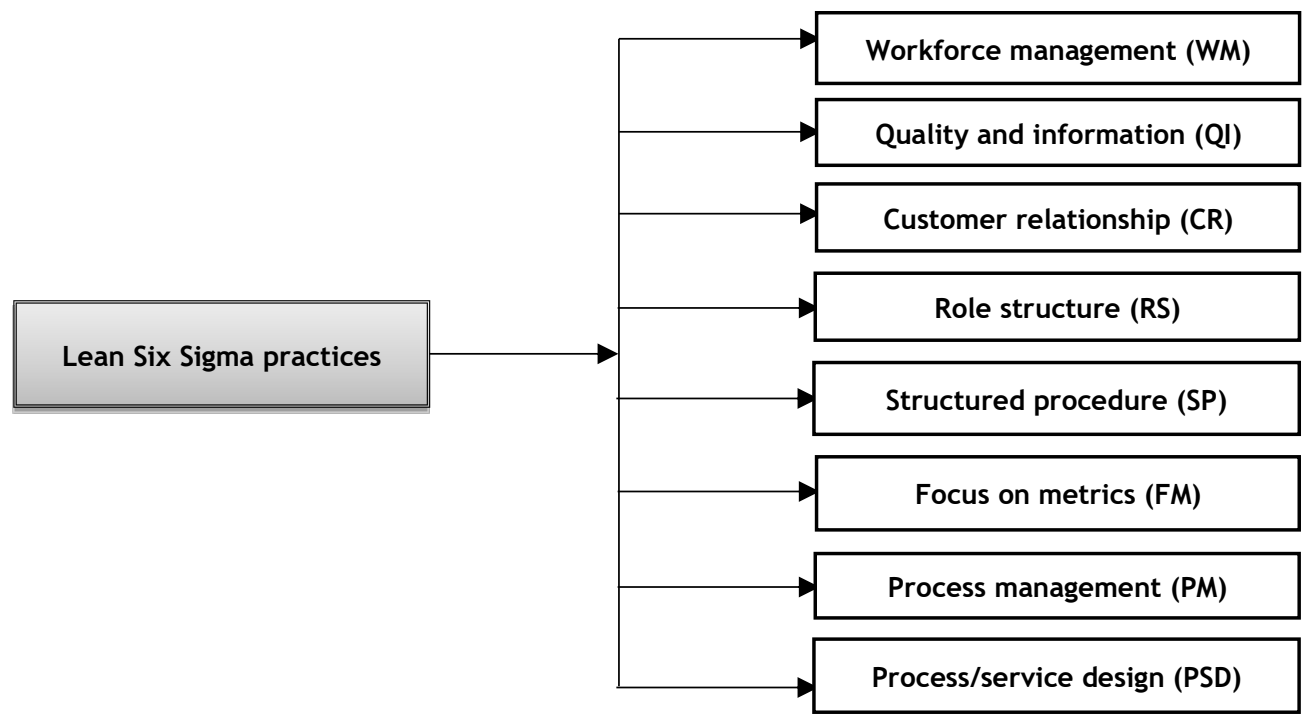

Figure 2: LSS practices (dependent variable)

\subsection{Relationship statements}

From the discussions in the literature review, it is evident that a limited amount of the literature relates to the study on the relationship between the LSS practices and leadership styles, and that no study has yet been done to discover the difference between the manufacturing and service sectors concerning leadership style and LSS practices, or the difference in the effect of leadership styles on LSS practices between the manufacturing and service sectors.

These research gaps directed the foundations for this study: to explore the relationship between leadership styles and LSS practices in a sample of Indian industries, and to compare the results for the manufacturing sector with those from the service sector. Based on the above discussions, the proposed relationship statements are listed in Table 1.

Table 1: Relationships that are investigated

\begin{tabular}{|c|l|}
\hline $\begin{array}{c}\text { Statement } \\
\text { no. }\end{array}$ & \multicolumn{1}{c|}{ Relationship statements } \\
\hline$S_{1}$ & The relationship between types of sectors and leadership styles \\
\hline$S_{2}$ & The relationship between types of sectors and LSS practices \\
\hline$S_{3}$ & The relationship between leadership styles and LSS practices in the manufacturing sector \\
\hline$S_{4}$ & The relationship between leadership styles and LSS practices in the service sector \\
\hline$S_{5}$ & The impact of leadership styles on LSS practices in the manufacturing and service sectors \\
\hline
\end{tabular}

\section{RESULTS AND DISCUSSION}

\subsection{Demographic details of the respondents}

The number of questionnaires that were filled in completely and found to be valid was 313 . Out of the 313 respondents, 188 were from the manufacturing sector, and the remaining 125 respondents were from the service sector, representing 60.1 per cent and 39.9 per cent respectively. The demographic details, based on the type of company, years of establishment, company turnover, and LSS roles, were analysed and compressed in the form of tables, as represented below in Table 2. 
Table 2: Demographic details of the respondents

\begin{tabular}{|c|c|c|c|c|}
\hline S. no. & \multicolumn{2}{|c|}{ Demographic variables } & Manufacturing sector & Service sector \\
\hline \multirow[t]{5}{*}{1} & \multirow[t]{4}{*}{ Type of company } & Public & 20 & 6 \\
\hline & & Private & 125 & 96 \\
\hline & & Joint venture & 12 & 12 \\
\hline & & Multinational & 31 & 11 \\
\hline & \multicolumn{2}{|c|}{ Total number of respondents } & 188 & 125 \\
\hline \multirow{7}{*}{2} & \multirow{6}{*}{ Years of establishment } & $<10$ & 14 & 10 \\
\hline & & $11-20$ & 17 & 4 \\
\hline & & $21-30$ & 20 & 4 \\
\hline & & $31-40$ & 7 & 8 \\
\hline & & $41-50$ & 48 & 47 \\
\hline & & $>50$ & 82 & 52 \\
\hline & \multicolumn{2}{|c|}{ Total number of respondents } & 188 & 125 \\
\hline \multirow[t]{8}{*}{3} & \multirow[t]{7}{*}{ Company turnover } & Less than INR 1 million & 1 & 2 \\
\hline & & INR 1-10 million & 13 & 4 \\
\hline & & INR $11-20$ million & 19 & 7 \\
\hline & & INR 21-30 million & 2 & 2 \\
\hline & & INR 31-50 million & 22 & 11 \\
\hline & & INR 41-50 million & 40 & 17 \\
\hline & & over INR 50 million & 91 & 82 \\
\hline & \multicolumn{2}{|c|}{ Total number of respondents } & 188 & 125 \\
\hline \multirow[t]{8}{*}{4} & \multirow[t]{7}{*}{ LSS roles } & Champion & 3 & 3 \\
\hline & & Sponsor & 3 & 0 \\
\hline & & Master Black Belt & 2 & 0 \\
\hline & & Black Belt & 46 & 21 \\
\hline & & Green Belt & 72 & 45) \\
\hline & & Team member & 48 & 34 \\
\hline & & No specific LSS position & 14 & 22 \\
\hline & \multicolumn{2}{|c|}{ Total number of respondents } & 188 & 125 \\
\hline
\end{tabular}

The analysis of the respondents' profile shows that most of the respondents belonged to private companies, followed by multinational companies in both the manufacturing and the service sectors. The majority of the respondents who participated in this survey belonged to companies that had survived in this competitive world for more than 50 years, followed by those in companies that had been established for 41-50 years, in both the manufacturing and the service sectors. Based on company turnover, the majority of the participants were from companies having a turnover greater than INR 50 million, followed by those with a turnover greater than INR 41-50 million in both sectors. Finally, the majority of the respondents were from the private sector, from companies that had been established for more than 50 years and that had a turnover of more than INR 50 million. Concerning the LSS roles, the respondents were mostly Green Belts followed, by Team Members and Black Belts. This data was found to be suitable for further analysis in order to study the developed relationship statements.

\subsection{Reliability and validity}

After summarising the demographic details of the respondents, the next step was to check the reliability and validity of the dimensions and the measurement items. The data analysis began with by assessing the collected data for its appropriateness for analysis. To complete a thorough data analysis, it was regarded as legitimate to pursue the methods laid out by Hair, Black, Babin, Anderson, and Tatham [58], which were to look for any data patterns that had been missed out, and to retain measurable statistical assumptions, distinguish the proof of anomalies, and review the skewness and kurtosis. After considering all of the above suggestions, the researcher found no missing data nor any anomalies. Moreover, the Cronbach's alpha for the estimates identified with the lower limits of acceptance was found to be that $\alpha>0.70$. In the light of this, all the measures were found to have considerable reliability. 
Table 3: Reliability test of the Independent and dependent variables

\begin{tabular}{|l|c|c|}
\hline \multicolumn{1}{|c|}{ Dimensions } & $\begin{array}{c}\text { Number of measurement } \\
\text { items }\end{array}$ & Cronbach's alpha \\
\hline Participative leadership style & 4 & 0.845 \\
\hline Supportive leadership style & 4 & 0.842 \\
\hline Instrumental leadership style & 4 & 0.841 \\
\hline Workforce management & 8 & 0.894 \\
\hline Quality and information & 6 & 0.885 \\
\hline Customer relationship & 5 & 0.843 \\
\hline Process management & 4 & 0.858 \\
\hline Focus on metrics & 4 & 0.853 \\
\hline Role structure & 4 & 0.867 \\
\hline Structured procedure & 4 & 0.860 \\
\hline Process/service design & 3 & 0.856 \\
\hline
\end{tabular}

To measure construct validity, dimension reduction techniques were used to determine the factor loadings. An exploratory factor analysis was carried out with the maximum likelihood method with varimax rotation to determine the communalities, eigen factors, and factor loadings respectively. Three of the leadership style dimensions - the participative, supportive, and instrumental leadership styles - were adopted from the work of Ogbonna and Harris [22], and were subjected to factor loading. Table 4 shows the factor loading, communalities, and eigenvalues of the exploratory factor analysis of the leadership style dimensions.

Table 4: Factor loadings, communalities, and eigenvalues for leadership styles

\begin{tabular}{|c|c|c|c|c|}
\hline Dimensions & Measurement items & Factor loadings & Communalities & Eigenvalues \\
\hline \multirow[t]{5}{*}{ Participative leadership style } & Listening to advice & 0.719 & 0.564 & \multirow[t]{4}{*}{3.988} \\
\hline & Consideration & 0.631 & 0.458 & \\
\hline & Consultation & 0.713 & 0.521 & \\
\hline & Considering subordinates & 0.772 & 0.636 & \\
\hline & Asking for suggestions* & 0.268 & 0.125 & \\
\hline \multirow[t]{4}{*}{ Instrumental leadership style } & Decision-making & 0.648 & 0.445 & \multirow[t]{4}{*}{1.470} \\
\hline & Explaining tasks & 0.658 & 0.465 & \\
\hline & Defining standards & 0.731 & 0.576 & \\
\hline & Scheduling work & 0.779 & 0.639 & \\
\hline \multirow[t]{4}{*}{ Supportive leadership style } & Personal welfare & 0.626 & 0.510 & \multirow[t]{4}{*}{1.178} \\
\hline & Being pleasant & 0.715 & 0.591 & \\
\hline & Little things & 0.779 & 0.630 & \\
\hline & Treating equally & 0.657 & 0.476 & \\
\hline
\end{tabular}

From the results, it was clear that one measurement item needed to be removed from the participative leadership style, as it had low factor loadings and communalities $(<0.4)$. Thus the factor analysis results showed that the three dimensions of leadership style had four measurement items each, and these were used for further study. The item marked '*' and written in italics were dropped from the study. Finally, it could be concluded that construct validity and reliability were maintained for this study.

\subsection{Testing of relationship statements}

\subsubsection{Relationship between types of sectors and leadership style}

The first relationship statement was framed to test whether there was any difference between the manufacturing and service sectors concerning leadership styles. Welch's t-test was used to study the differences between the three leadership styles in the manufacturing and service sectors, as the sample size was unequal. The results are summarised in Table 5.

Table 5: Welch's t-test results for the independent variables

\begin{tabular}{|c|c|c|c|c|c|c|}
\hline \multirow{2}{*}{$\begin{array}{l}\text { Leadership style } \\
\text { dimensions }\end{array}$} & \multicolumn{2}{|c|}{$\begin{array}{l}\text { Manufacturing } \\
\text { sector }(\mathrm{N}=188)\end{array}$} & \multicolumn{2}{|c|}{$\begin{array}{l}\text { Service sector } \\
\quad(N=125)\end{array}$} & \multirow[t]{2}{*}{$\begin{array}{c}\text { Mean } \\
\text { difference }\end{array}$} & \multirow[b]{2}{*}{ 'p' value } \\
\hline & Mean & SD & Mean & SD & & \\
\hline Participative leadership style & 16.24 & 2.619 & 16.74 & 2.133 & -0.50 & 0.070 \\
\hline Instrumental leadership style & 16.34 & 2.223 & 17.05 & 2.207 & -0.71 & $0.006^{*}$ \\
\hline Supportive leadership style & 16.07 & 2.597 & 16.86 & 2.078 & -0.79 & $0.003^{*}$ \\
\hline
\end{tabular}

*Significant at $p=0.05$

SD: Standard deviation 
Table 5 above shows that the two types of leadership style (instrumental and supportive) had significant differences $(p<0.05)$. The participative leadership style showed no significant difference $(p>0.05)$, as it was practised in both sectors; this is helpful in promoting LSS practices, as this style makes leaders more interactive with their subordinates in consulting, seeking advice, and inviting suggestions. The instrumental leadership style in the manufacturing sector helps to define standardised work procedures that enable employees or subordinates to promote and discipline their process-based activities further, based on the standardised work procedures that are formalized, explained, and provided by the leaders. In the case of the service sector, the scenario differs completely. These leaders work mainly with their team members in project-based environments, and the decision-making lies mainly with the leaders; discussions might be held with subordinates in some cases. The standards for work procedures are designed based on the leader's decision, and tasks are explained to team members by the leaders. A supportive leadership style mainly shows more concern for the subordinates or team members. The leaders help their team members to work in a pleasant environment, encourage them, treat all the team members equally, and consider their welfare. Team members are also encouraged by their team leaders to improve in their work.

The service sector was found score highest for the instrumental leadership style, which promotes decisionmaking, scheduling and explaining tasks, and defining standards. The mean difference results show that the service sector does better than the manufacturing sector in all three types of leadership style. Finally, it can be concluded that the participative leadership style is commonly practised in both sectors, but that there are differences in how the other two styles are practised.

Thus the first relationship statement proves that there is a significant difference between the manufacturing and service sectors in the case of the instrumental and supportive leadership styles, but no significant difference in the participative leadership style while practising LSS.

\subsubsection{The relationship between types of sector and LSS practices}

The second relationship statement tested whether there was any difference between the manufacturing and service sectors in their LSS practices. As the sample sizes were unequal, Welch's t-test was used to study the differences between the eight LSS practices in the manufacturing and service sectors. The results are summarised in Table 6.

Table 6: Welch's t-test results for the dependent variables

\begin{tabular}{|c|c|c|c|c|c|c|}
\hline \multirow[b]{2}{*}{ LSS practices dimensions } & \multicolumn{2}{|c|}{$\begin{array}{l}\text { Manufacturing } \\
\text { sector }(\mathrm{N}=188)\end{array}$} & \multicolumn{2}{|c|}{$\begin{array}{l}\text { Service sector } \\
(N=125)\end{array}$} & \multirow[t]{2}{*}{$\begin{array}{c}\text { Mean } \\
\text { difference }\end{array}$} & \multirow{2}{*}{$\begin{array}{c}\text { 'p' } \\
\text { value }\end{array}$} \\
\hline & Mean & SD & Mean & SD & & \\
\hline Workforce management & 31.39 & 1.604 & 31.35 & 1.598 & 0.04 & 0.822 \\
\hline Quality and information & 23.23 & 1.033 & 23.22 & 1.054 & 0.01 & 0.934 \\
\hline Customer relationship & 21.04 & 2.743 & 21.74 & 2.310 & -0.70 & $0.015^{*}$ \\
\hline Process management & 17.60 & 1.522 & 17.70 & 1.499 & -0.10 & 0.586 \\
\hline Focus on metrics & 16.17 & 2.158 & 16.70 & 2.156 & -0.53 & $0.036^{*}$ \\
\hline Role structure & 16.40 & 1.825 & 16.46 & 2.231 & -0.06 & 0.786 \\
\hline Structured procedure & 12.74 & 1.534 & 13.11 & 1.608 & -0.37 & $0.042^{*}$ \\
\hline Process/service design & 17.47 & 1.479 & 17.78 & 1.553 & -0.31 & 0.079 \\
\hline
\end{tabular}

From Welch's t-test, it was noted that most of the practices showed insignificant differences between the two sectors except for customer relationship, focus on metrics, and a structured procedure. From the mean difference, it was found that the majority of the practices (customer relationship, process management, focus on metrics, role structure, structured procedure, and process/service design) were performing better in the service sector than in the manufacturing sector. Customers are assessed, and feedback is obtained to improve the service in order to have close contact with them and to involve them directly in projects so that the services meet their requirements. Managing the processes by using data analytics and preventive maintenance are the main efforts made by the managers and employees in the manufacturing sector. The service sector also performs data analytics, predictive analytics, and big data techniques to meet the schedules of processes. Performance measurement systems are the main method used to yield information related to business performance, employee performance, process-wise performance, and project-related performance measures, which help the top management to define their strategies and goals. Businesslevel, process-level, and employee-level measures are more focused on manufacturing, but in the case of the service sector, all the performance measures are taken into consideration. Both sectors have a beltbased recognition approach to Six Sigma-certified employees, and specific roles and responsibilities are also assigned to them. The DMAIC (Define, Measure, Analyse, Improve and Control) procedure and the quality tools used differ between the sectors, and are tailor-made and implemented as per company 
regulations. A complete review of the project output is performed, and all the departments are involved in the design-related activities so that a standardised design output is derived and followed to achieve productivity.

From the ' $p$ ' value, it can be said that five practices were found to be integrated more successfully in the service sector than in the manufacturing sector. Based on the nature of the service industries surveyed, customer relationships, focus on metrics, and structured procedure were found to have weak scores. Customers are the most important foundation for every company, and the relationship is the most important factor. Retaining customers by having a good relationship with them is the main target of companies nowadays. The focus on metrics will not be the same in both sectors, as some might focus on financial performance, some on employees' performance, and some on quality performance. The LSS methodology follows a structured procedure, DMAIC, and quality management tools are used; and this might sometimes be slightly modified to meet the company's requirements.

Finally, it can be said that the service sector is more interested in LSS-based practices - role structure, structured procedure, and focus on metrics - than the manufacturing sector, as these three practices relate purely to belt-based roles and responsibilities and the DMAIC procedure, and are critical to quality factors aligning with their performance measurements. Thus the second relationship statement has shown that there is a significant difference between the sectors, based on LSS practices.

From the two relationship statements discussed above, it can be concluded that there is a significant difference between the two sectors in their leadership styles and LSS practices. This has led the researcher to proceed further in studying the relationship between leadership styles and LSS practices in both sectors, and in studying the impact of leadership styles on LSS practices.

\subsubsection{The relationship between leadership styles and LSS practices in the manufacturing sector.}

This relationship statement framed aimed to show whether leadership styles played any significant role in the improvement of LSS practices, and whether there was any relationship between the two variables in the manufacturing context. Simple linear regression was used to test each of the three styles against LSS practices, and multiple linear regression was used to test the styles together against LSS practices. Table 7 summarises the regression values.

Table 7: Regression analysis for manufacturing sector

\begin{tabular}{|l|c|c|c|c|}
\hline \multicolumn{1}{|c|}{ Dimensions } & F value & R & R sq. & Sig. \\
\hline Participative leadership style & 160.957 & 0.681 & 0.464 & 0.000 \\
\hline Supportive leadership style & 155.550 & 0.675 & 0.455 & 0.000 \\
\hline Instrumental leadership style & 139.388 & 0.655 & 0.428 & 0.000 \\
\hline All leadership styles & 188.323 & 0.709 & 0.503 & 0.000 \\
\hline
\end{tabular}

*Significant at $\mathrm{p}=0.05$

All three styles showed significant results. The value of $\mathrm{R}$ square was 0.503 , which showed that 50.3 per cent of the variation in LSS practices was a result of following all three styles. The Pearson correlation coefficient $(R)$ was found to be 0.709 between the two variables, and ranged between 0.655 and 0.681 , which supported the statement that the three styles helped to improve LSS practices in the manufacturing sector.

\subsubsection{The relationship between leadership styles and LSS practices in the service sector}

The fourth relationship statement was framed to show whether leadership styles played an important role in the improvement of LSS practices, and whether there was any association between the independent and dependent variables in the service context. Multiple linear regression was used to test the relationship of all the styles together with LSS practices, while simple linear regression was used to test each of the three styles against LSS practices. Table 8 shows the regression output.

Table 8: Regression analysis for service sector

\begin{tabular}{|l|c|c|c|c|}
\hline \multicolumn{1}{|c|}{ Dimensions } & F & R & R sq. & 'p' value \\
\hline Participative leadership style & 56.832 & 0.562 & 0.316 & 0.000 \\
\hline Supportive leadership style & 93.522 & 0.657 & 0.432 & 0.000 \\
\hline Instrumental leadership style & 148.520 & 0.740 & 0.547 & 0.000 \\
\hline All leadership styles & 125.133 & 0.710 & 0.504 & 0.000 \\
\hline
\end{tabular}

*Significant at $p=0.05$ 
R square was found to be 0.504 , which indicated that 50.4 per cent of the variation in LSS practices was because the service sector adopted all three styles. The Pearson correlation coefficient $(R)$ was found to be 0.710 between the independent and dependent variables, and ranged between 0.562 and 0.740 , which supported the relationship statement that the three styles helped to improve LSS practices in the service sector.

\subsubsection{Impact of leadership style on LSS practices in both sectors}

The last relationship statement was framed to test whether leadership style had an impact on LSS practices. The results are shown in Table 9.

Table 9: Results of impact of leadership style on LSS practices

\begin{tabular}{|c|l|l|l|l|l|}
\hline Variable & \multicolumn{1}{|c|}{ Sector } & N & Mean & F & Sig. \\
\hline \multirow{2}{*}{ Leadership styles } & Manufacturing & 188 & 48.66 & 6.738 & 0.010 \\
\cline { 2 - 6 } & Service & 125 & 50.64 & & \\
\hline
\end{tabular}

*Significant at $\mathrm{p}=0.05$

The ANOVA results were used to explain the impact of leadership styles on LSS practices. The mean difference highlighted that the service sector had done better than the manufacturing sector. The output gave good results, as the relationship was found to reveal no significant difference between the sectors. Thus it could be concluded that leadership styles had a great impact on improved LSS practices in both sectors. From all the hypotheses that were proved, it could be concluded that the LSS practices and leadership styles discussed here could be relevant to both the manufacturing and the service sectors.

\section{CONCLUSION}

The purpose of this study was to determine the impact of leadership style on the improvement of LSS practices. A questionnaire was developed and distributed to 400 respondents from the manufacturing and service sectors in Chennai, with a response rate of about 78 per cent. Welch's test proved that there was a significant difference between the manufacturing and service sectors in the case of the instrumental and supportive leadership styles, but no significant difference in the participative leadership style while practising LSS. From the result of Welch's t-test, it was proved that the service sector was more interested in the LSS-based practices of role structure, structured procedure, and focus on metrics than was the manufacturing sector, where those three practices were based purely on belt-based roles and responsibilities and the DMAIC procedure, and were critical to quality factors aligning with their performance measurements. Thus it has been proved that there is a significant difference between the two sectors, based on LSS practices. To find the relationship between the two dimensions, a regression analysis was carried out, which proved that all three types of leadership style had a positive and significant relationship with LSS practices in both the manufacturing and the service sectors.

\section{RECOMMENDATIONS}

It is strongly recommended that the three types of leadership style - participative, supportive, and instrumental - possess the characteristics required to promote and improve LSS practices in an organisation. The soft aspects rather than the hard aspects of quality management are focused on more in this paper because the researcher strongly believed that, if the management-based aspects were clear and smooth in any organisation, excellent and positive improvements in LSS practices could be seen. This study could be used as a preliminary guide for leaders to enhance their leadership in an organisation that practises LSS.

\section{REFERENCES}

[1] Spector, R.E. 2006. How constraints management enhances lean and six sigma. Supply Chain Management Review, 10(1), $42-47$.

[2] Thomas, A., Barton, R. \& Chuke-Okafor, C. 2009. Applying Lean Six Sigma in a small engineering company: A model for change. Journal of Manufacturing Technology Management, 20(1), 113-129.

[3] Assarlind, M., Gremyr, I. \& Bäckman, K. 2013. Multi-faceted views on a Lean Six Sigma application. International Journal of Quality and Reliability Management, 30(4), 387-402.

[4] Snee, R.D. 2010. Lean Six Sigma: Getting better all the time. International Journal of Lean Six Sigma, 1(1), 9-29.

[5] Achanga, P., Shehab, S., Roy, R. \& Nelder, G. 2006. Critical success factors for lean implementation within SMEs. Journal of Manufacturing Technology Management, 17(4), 460-471.

[6] Pandey, A. 2007. Strategically focused training in Six Sigma way: A case study. Journal of European Industrial Training, 31(2), 145-162. 
[7] Laureani, A. \& Antony, J. 2012. Critical success factors for the effective implementation of Lean Sigma: Results from an empirical study and agenda for future research. International Journal of LSS, 3(4), 274-283.

[8] Jacobs, M. 2015. Cultural impact on Lean Six Sigma and corporate success: Causal analyses considering the effects of national culture and leadership. Wiesbaden: Springer Gabler.

[9] Nogueira, D., Sousa, P. \& Moreira, M. 2018. The relationship between leadership style and the success of Lean management implementation. Leadership \& Organization Development Journal, 39(6), 807-824.

[10] Womack, J.P. \& Jones, D.T. 1996. Lean thinking. New York: Simon and Schuster.

[11] Schroeder, R.G., Linderman, K., Liedtke, C. \& Choo, A.S. 2008. Six Sigma: Definition and underlying theory. Journal of Operations Management, 26(4), 536-554.

[12] Arnheiter, E.D. \& Maleyeff, J. 2005. The integration of Lean Management and Six Sigma. The TQM Magazine, 17(1), 5-18.

[13] Karthi, S., Devadasan, S.R. \& Murugesh, R. 2011. Integration of Lean Six-Sigma with ISO 9001: 2008 standard. International Journal of Lean Six Sigma, 2(4), 309-331.

[14] Salah, S., Rahim, A. \& Carretero, J.A. 2010. The integration of Six Sigma and lean management. International Journal of LSS, 1(3), 249-274.

[15] Dahlgaard, J.J. \& Dahlgaard-Park, S.M. 2006. Lean production, Six Sigma quality, TQM and company culture. The TQM Magazine, 18(3), 263-281.

[16] Kumar, M., Antony, J., Madu, C., Montgomery, D. \& Park, S. 2008. Common myths of Six Sigma demystified. International Journal of Quality \& Reliability Management, 25(8), 878-95.

[17] Zu, X., Robbins, T.L. \& Fredendall, L.D. 2010. Mapping the critical links between organizational culture and TQM/Six Sigma practices. International Journal of Production Economics, 123(1), 86-106.

[18] McNamara, C. 2008. Field guide to leadership and supervision. Minneapolis, MN: Authenticity Consulting.

[19] Chemers, M.M. 2002. Efficacy and effectiveness: Integrating models of leadership and intelligence. In Ott, J.S., Parkes, S.J. and Simpson, R.B. (eds). Classic readings in organizational behaviour, Wadsworth, Belmont, CA, 11431.

[20] Lok, P. \& Crawford, J. 2004. The effect of organisational culture and leadership style on job satisfaction and organisational commitment. Journal of Management Development, 23(4), 321-338.

[21] Van Fleet, D.D. \& Griffin, R.W. 2006. Dysfunctional organizational culture: The role of leadership in motivating dysfunctional work behaviours. Journal of Managerial Psychology, 21(8), 698-708.

[22] Harris, L.C. \& Ogbonna, E. 2000. Leadership style, organizational culture, and performance: Empirical evidence from UK companies. International Journal of Human Resource Management,11, 766-788.

[23] Koopman, P.L. \& Wierdsma, A.F.M. 1998. Participative management. In Drenth, P.J.D., Thierry, H., De Wolff, C.J. (eds). Handbook of work and organizational psychology, 2nd ed., Vol. III, 297-324. East Sussex: Hove Psychology Press.

[24] Horsfall, C. (ed.). 2001. Leadership issues: Raising achievement. London: Learning and Skills Development Agency.

[25] Bowers, D.G. \& Seashore, S.E. 1966. Predicting organizational effectiveness with a four-factor theory of leadership. Administrative Science Quarterly, 11, 238-263.

[26] Halpin, W.W. \& Winer, R.J. 1957. A factorial study of the leader behavior description. In Stogdill, R.M., Coons A.E. (eds). Leader behavior: Its description and measurement, Columbus: The Ohio State University, Bureau of Business Research, 39-51.

[27] Likert, R. 1961. New patterns of management. Tokyo, Japan: McGraw Hill Kogakusha Ltd.

[28] Deci, E.L., Connell, J.P. \& Ryan, R.M. 1989. Self-determination in a work organization. Journal of Applied Psychology, 74, 580-590.

[29] House, R.J. 1971. A path-goal theory of leadership effectiveness. Administrative Science Quarterly, 16, $321-328$.

[30] Harris, L.C. \& Ogbonna, E. 2001. Leadership style and market orientation: An empirical study. European Journal of Marketing, 35, 744-764.

[31] Antonakis, J. \& House, R.J. 2002. The full-range leadership theory: The way forward. In Avolio, B. and Yammarino, F. (eds). Transformational and charismatic leadership: The road ahead, Amsterdam: JAl - Elsevier Science,2, 333.

[32] Antonakis, J. \& House, R. 2004. On instrumental leadership: Beyond transactions and transformations. Omaha: UNL Gallup Leadership Institute Summit.

[33] Rowold, J. 2014. Instrumental leadership: Extending the transformational-transactional leadership paradigm. German Journal of Human Resource Management, 28(3), 367-390.

[34] Bass, B.M. \& Avolio, B.J. 1994. Transformational leadership and organizational culture international. Journal of Public Administration, 17, 541-554.

[35] Brown, M.G. 2008. The pocket guide to the Malcolm Baldrige Award criteria, Chap. 1. New York: Taylor and Francis Group.

[36] Idris, F. \& Ali, K. 2008. The impacts of leadership style and best practices on company performances: Empirical evidence from business firms in Malaysia. Total Quality Management and Business Excellence, 19(1), 165-173.

[37] Khan, M.A. 2010. Evaluating the Deming management model of total quality in telecommunication industry in Pakistan: An empirical study. International Journal of Business and Management, 5(9), 46-59.

[38] Khan, M.A. 2011. Total quality management and organizational performance-moderating role of managerial competencies. International Journal of Academic Research, 3(5), 453-458.

[39] Waldman, D.A. 1993. A theoretical consideration of leadership and total quality management. Leadership Quarterly, 4(1), 65-79.

[40] Dean, J.W., Jr. \& Bowen, D.E. 1994. Management theory and total quality: Improving research and practice through theory development. Academy of Management Review, 19(3), 392-418.

[41] Deming, W.E. 1994. Leadership for quality. Executive Excellence, 11(6), 3-5.

[42] Kirkpatrick, S.A. \& Locke, E.A. 1991. Leadership: Do traits matter? The Executive, 5(2), 48-60. 
[43] Albliwi, S., Antony, J., Halim Lim, S.A. \& Van der Wiele, T. 2014. Critical failure factors of Lean Six Sigma: A systematic literature review. International Journal of Quality and Reliability Management, 31(9), $1012-1030$.

[44] Hahn, G.J., Hill, W.J., Hoerl, R.W. \& Zinkgraf, S.A. 1999. The impact of six sigma improvement: A glimpse into the future of statistics. The American Statistician, 53(3), 208-215.

[45] Pande, P., Neuman, R. \& Cavanagh, R. 2000. The Six Sigma way: How GE, Motorola, and other top companies are honing their performance. New York, NY: McGraw-Hill Professional.

[46] Timans, W., Antony, J., Ahaus, K. \& Van Solingen, R. 2012. Implementation of LSS in small- and medium-sized manufacturing enterprises in The Netherlands. Journal of the Operational Research Society, 63(3), 339-353.

[47] Laureani, A. \& Antony, J. 2017. Leadership and Lean Six Sigma: A systematic literature review. Total Quality Management and Business Excellence, 30(1-2),53-81.

[48] Lakshman, C. 2006. A theory of leadership for quality: Lessons from TQM for leadership theory. Total Quality Management and Business Excellence, 17(1), 41-60.

[49] Berson, Y. \& Linton, J. 2005. An examination of the relationships between leadership style, quality, and employee satisfaction in R\&D versus administrative environments. R\&D Management, 35(1), 51-60.

[50] Ovretveit, J. 2005. The leader's role in quality and safety improvement: $A$ review of research and guidance, $4^{\text {th }}$ ed. Stockholm, Sweden: Association of County Councils.

[51] Sousa, R. \& Voss, C. 2002. Quality management re-visited: A reflective review and agenda for future research. Journal of Operations Management, 20(1), 91-109.

[52] Van Assen, M.F. 2018. Exploring the impact of higher management's leadership styles on Lean management. Total Quality Management \& Business Excellence, 29(11-12), 1312-1341.

[53] Kumar, V. \& Sharma, R.R.K. 2018. Leadership styles and their relationship with TQM focus for Indian firms: An empirical investigation. International Journal of Productivity and Performance Management, 67(6), 1063-1088.

[54] Alefari, M., Almanei, M. \& Salonitis, K. 2020. Lean manufacturing, leadership, and employees: The case of UAE SME manufacturing companies. Production \& Manufacturing Research, 8(1), 222-243.

[55] Burawat, P. 2019. The relationships among transformational leadership, sustainable leadership, lean manufacturing, and sustainability performance in Thai SMEs manufacturing industry. International Journal of Quality \& Reliability Management, 36(6), 1014-1036.

[56] Puffer, S.M. \& McCarthy, D.J. 1996. A framework for leadership in a TQM context. Journal of Quality Management, 1(1), 109-130.

[57] Sekaran, U. \& Bougie, R. 2013. Research methods for business: A skill-building approach, 6th ed. New York: Wiley.

[58] Hair, J.F., Black, C.W., Babin, B.J., Anderson, R.E. \& Tatham, R.L. 2006. Multivariate data analysis, 6th ed. Upper Saddle River, New Jersey: Prentice-Hall. 